\title{
Presentation of the Hungarian Publications of the Magyar Nemzeti Bank Published between 1950 and 1990 from a Visual Communication Perspective*
}

\section{Ákos Vajas}

\section{Introduction}

Upon hearing the name 'Magyar Nemzeti Bank', most people unwittingly think of the main building near Szabadság tér in Budapest. This comes as no surprise, since it is a distinctive, one-of-a-kind building, and its architectural style, the groups of statues on its façade, and the windows adorning the interior are all astonishing works of leading architects, sculptors and applied artists. The building has housed the Bank's professional activities for many decades and has symbolic significance in Hungarian and international financial and economic policy. Despite the fact that the Bank's main building has been presented in many books through the painstakingly meticulous work of various authors, the professionals playing a part in the Bank's past, their community and engagement as well as the Bank's publications, i.e. the journals circulated internally or externally that provided a publishing opportunity for everyday information and experts' serious professional works, are hardly mentioned. The various publications are interesting and valuable not only because of their visual appearance, but also because they represent a real rarity as regards to their content. If we go beyond the surface, we can take a peek behind the curtain and get to know, understand and in a sense relive all of the events in the Bank's distant past (e.g. personal recollections from during and after the Second World War, the 1956 Revolution and its aftermath within the Bank). The accounts as well as the illustrations, caricatures and drawings found here are of exceptional quality and poke fun at the everyday events at an organisation and a discipline (economics) as a whole. Furthermore, sometimes we can also see the artists' honest self-reflection about the social and political structure and atmosphere between 1945 and 1990. This short description, which is far from comprehensive, was compiled on the one hand to pique readers' interest in visual communication, a topic rarely in the focus in

* The views expressed in this paper are those of the author(s) and do not necessarily reflect the offical view of the Magyar Nemzeti Bank.

Vajas Ákos is a project coordinator at the Magyar Nemzeti Bank. E-mail: vajasa@mnb.hu

The Hungarian manuscript was received on 11 September 2017.

DOI: http://doi.org/10.25201/FER.16.4.201214 
economics, and on the other hand to pay tribute to the Bankszemle (Bank Review), and commemorate it on the 60th anniversary of its first publication.

\section{Bankszemle}

The Bankszemle, ${ }^{1}$ first published in June 1957 (Figure 1) was the scientific journal of the Magyar Nemzeti Bank, first prepared for internal use and circulation only. The publication was intended for professionals and published in 350 copies, which was gradually increased to 1,000. On account of its private circulation, it was written and read mainly by the Bank's staff. Later, in parallel with rebranding and pagesetting innovations, circulation of the journal was widened, thereby reaching several financial institutions, organisations and companies, and professionals from outside

Figure 1
Rebranding of the Bankszemle
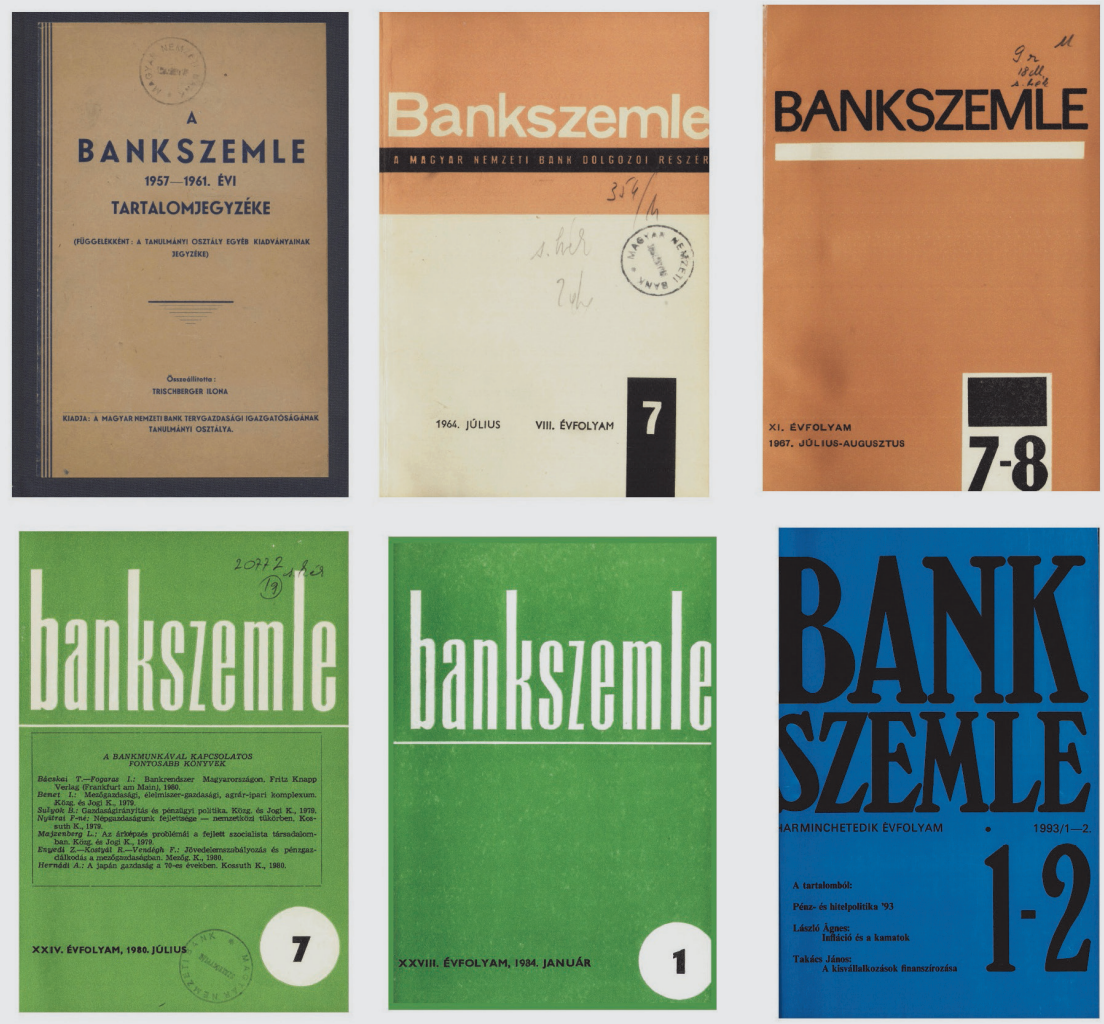

${ }^{1}$ The Bankszemle was published until 2001, when it was replaced by the Financial and Economic Review as a major Hungarian scientific journal in the fields of economics and finance. 
the Bank were also allowed to publish in it. As a result, the number of subscriptions to the journal jumped from around 1,000 to over 3,000, which had made it a major journal in the country. We can see that on the outside, the publication changed somewhat over the decades, but its topics remained the same. The periodical's new look and especially the page-setting of the publication's inside pages were intended to enhance the quality and prestige of the professional content published. ${ }^{2}$ It appeared as an 80-page publication for a long time, and then the number of pages was reduced to 64 , thereby making the whole work leaner. Thanks to new page-setting technologies, it was possible to increase the length of the contents, and the readability of the texts was aided by modification of the page layout (e.g. two-column pages).

\section{The Forint magazine}

The Forint, the journal of the staff of the Magyar Nemzeti Bank, was first published on 15 August $1950 .{ }^{3}$ Its forerunner was called Bankújság (Bank Journal), ${ }^{4}$ and its sister papers were the Fillér ${ }^{5}$ and the Bankó (Bank Note) (Figure 2-3). ${ }^{6}$ Due to paper shortages, the Forint's publication was interrupted in the autumn of 1951, and it only became available again in $1957 .^{7}$ This internal-circulation magazine was one of the main platforms for the Bank's active and retired employees for social interaction and voicing their opinion. The paper entitled Magyar Nemzeti Bank Dolgozóinak Lapja (Journal of the Staff of the Magyar Nemzeti Bank), which was occasionally called Üzemi Híradó (Operational News), is one of the most authentic sources for obtaining profound insight into everyday life at the Bank in the past.

\footnotetext{
${ }^{2}$ The editor-in-chief, Dr János Zádori, said the following about the necessity of rebranding in the January 1986 edition of the Forint magazine (Page 11): "The Bankszemle had become obsolete, it was the only small-circulation periodical in Hungary. In such a journal with second-rate typography and bland cover, even top-quality works could not make an impact."

${ }^{3}$ In its heyday, around 1975, approximately 3,600 copies of the journal were published, which was later slowly and gradually reduced. As a result, the initially subscription-based system was replaced by a free-or-charge model at the turn of the 1990s, which was to stop the plummeting circulation of the journal.

${ }^{4}$ The paper existed between 21 December 1949 and the end of July 1950 (Botos - Botos, 2004).

${ }^{5}$ It was published by the Hungarian Communist Youth Association (KISZ), and its contents and quality were a far cry from those of the Forint.

${ }^{6}$ This was the official publication of the Hungarian Banknote Printing Company and was first published in April 1958.

${ }^{7}$ After June 1953, the social information provision function of the Forint was taken over by the Híradó, which was published in a stencilled form.
} 


\section{Figure 2}

Transformation of the covers of the Bankújság between 1949 and 1950, and the Forint between 1950 and 1989

(Part 1)
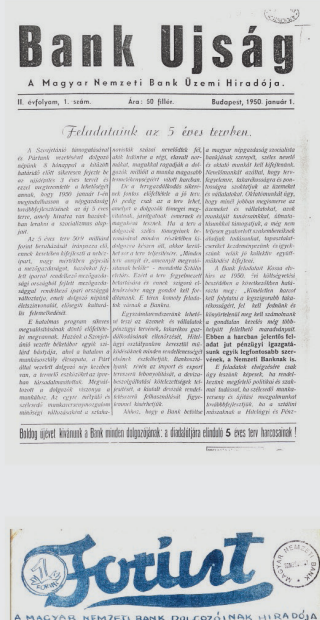

A DICSÓSÉCES MACYARTANACS KOZZTA'RSASA'C KIKIALLTA'SA'NAK

degr 0 Évfordulója
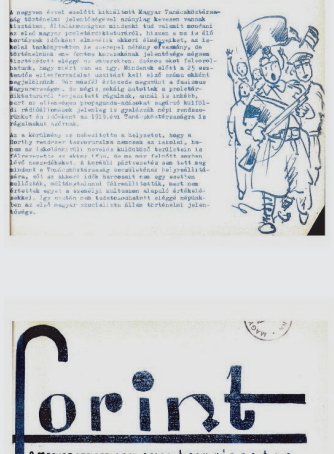

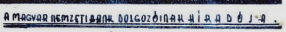

incousesye

1950.

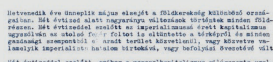

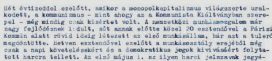

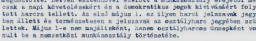

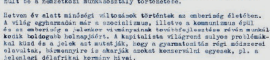
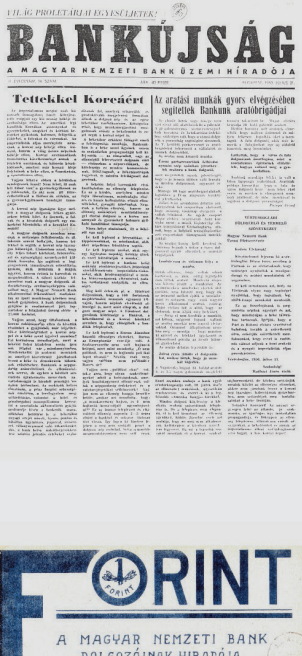

MAGपAR MEMZETI BA BK
DOLGOZÓINAK HIRADÓJA

A POLCA'RI TORVENYKONYY

JELENTÖSÉGE A BANK MUNKATERÜLETEN

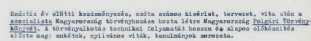

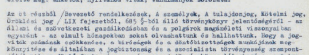

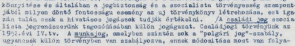

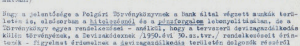

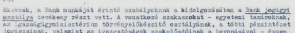

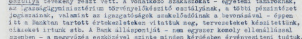

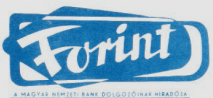

BANKUNK AZ ÚJ MECHANIZMUSBAN

$5=-3-5=5$
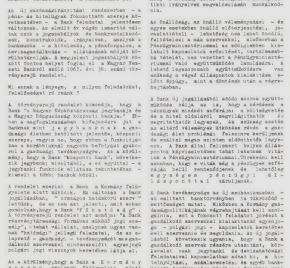
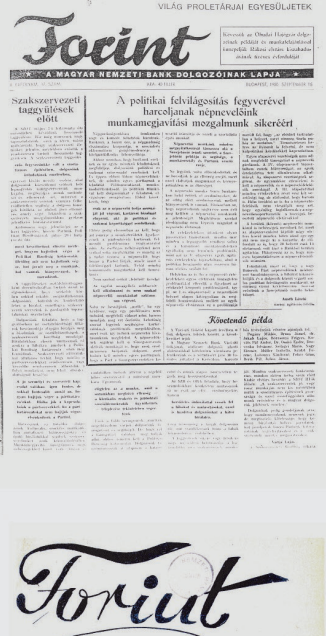

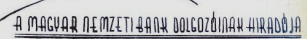

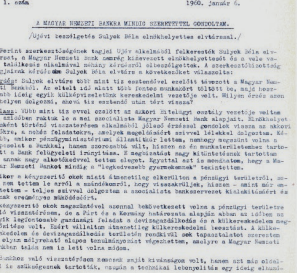

HORINT
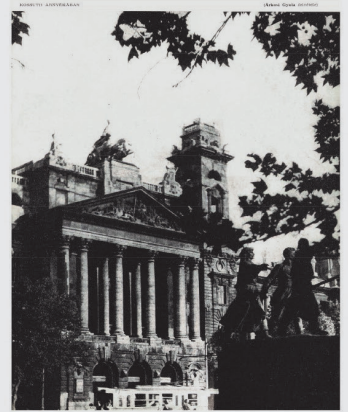


\section{Figure 3}

Transformation of the covers of the Forint between 1950 and 1989

(Part 2)
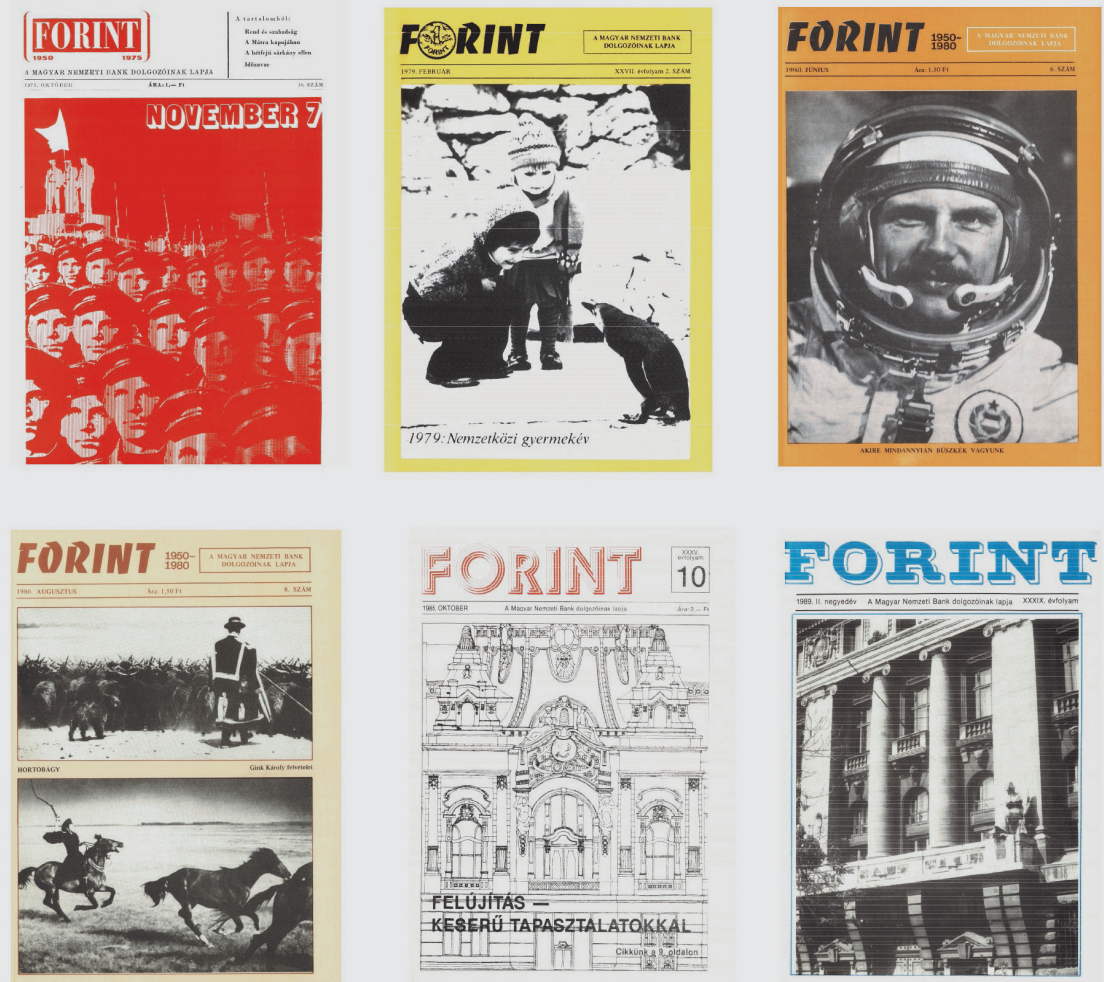

The journal was produced by an external printing house (Kossuth Nyomda) from 1969, which was replaced by printing within the Magyar Nemzeti Bank in 1979. This transition shortened printing times and brought about technological innovations in connection with production. New page-setting opportunities arose, which enabled the expansion and renewal of the contents of the journal on the one hand, and facilitated and enhanced the readability and structuring of the content on the other hand. These innovations had a positive impact, not only on the text but also on the visual content. One of the most striking examples for this was the change in the content and visual appearance of the journal's cover and header, which was fine-tuned over time, and became increasingly varied and exciting. Textbased and monochrome covers were replaced by ones with a colour background, and they were illustrated initially with drawings and then with black-and-white photographs, and after the 1990s with colour photographs. Thanks to page-setting 
technology, a balance was struck between the text and the images in the journal, as the illustrations within the text gained increasing prominence, thereby supporting and complementing the message of the written content. Moreover, caricatures shaping readers' opinion also appeared as independent, unique visual means of communication.

These focused on economics and general topics related to economics and finance (e.g. the "Közgazdasági kislexikon" (Concise Encyclopaedia of Economics) series or the "Értelmező bankszótár" (Dictionary of Banking Terms) series) on the one hand, and were representations of the various problems and situations in the everyday life of the Bank (e.g. lack of space in the Bank, the crowded rooms, the elevator that was perpetually out of order) on the other hand. Completely independent from these, we can of course find drawings addressing general social issues (e.g. the "Fintor" (Grimace) series). One of the special features of the journal was the illustrations on half a page or an entire page that were published quite frequently and that may bring to mind the currently popular, storytelling images.

Of course, the Forint also contained political statements, notices and reports characteristic of the age, mainly in the first half of the paper. The journal's special columns stood out from this (e.g. "Bankokos Manci", "Fintor", "Fullánk", "Bankenciklopédia”, "Értelmező bankszótár" (Know-All Mary in the Bank, Grimace, Sting, Banking Encyclopaedia, Dictionary of Banking Terms)) and humorous writings in verse (e.g. "Tűnődő Bankos Sebestyén" (George, the Pondering Banker)). The one-off or serial publication of these made the paper distinctive, unique and also more personal and casual for the readers. In addition to the traditional pieces, reports and portrayals depicting the everyday life and the various events in the Bank as well as the institution's sporting and cultural life, which were later enriched by photographs, articles with a more critical and scathing tone were also included (e.g. cutting red tape, comprehensible communication, bland and expensive food in the canteen, overcrowding, wasting working time).

The circulation and print run of the journal was strongly influenced by the active headcount in the Bank, which started slowly diminishing in 1972, and then from 1986 this decline continued at an increasing pace. Despite the continuous attempts to renew the journal, the downward trend could not be halted, which was a recurring problem until publication was terminated.

\subsection{The secret graphic artist of the Forint magazine}

The overwhelming majority of the illustrations and drawings between 1945 and 1978 were prepared by Dr Herbert Enyvvári, a lawyer at the Magyar Nemzeti Bank. However, his life was much more adventurous than just this. Born in 1916, drawing and graduating from the Academy of Fine Arts were his passions from his childhood. After his school leaving exam in 1934, he enrolled to the Legal and Political Science faculty of the Pázmány Péter Catholic University at his father's 
insistence. He continued to draw all throughout his years at the university, getting orders from several publishers (e.g. Athenaeum, Dante, Cserépfalvi, Révai), and collaborating with Zsigmond Móricz, Frigyes Karinthy among others, and he also worked together with folk authors Géza Fejes and József Darvas. The books he illustrated (e.g. the tales of Gusztáv Bernáth or Háry János legújabb kalandjai (The Latest Adventures of János Háry) by István Tamás) made him popular not only in Hungary but also at the international level. He received his degree in 1939 and then enlisted in the army. He only returned home in 1943, due to a shrapnel wound sustained on the front. At his father's insistence, he started looking for a respectable job and began working at the Magyar Nemzeti Bank. That same year, he commenced work on the illustration to Cervantes' Don Quijote published in the translation of Miklós Radnóti. A deep and close friendship developed between the poet and the illustrator. In the summer of 1944, he asked for permission to return to the front, where he was wounded again and then captured during the Soviet advance. He only returned to the Bank in 1945 as an expert in labour law, where he was later also in charge of preparing the internal rules of procedure. That was when he started drawing fervently in the Forint. He married his wife, Éva Rákóczy, ${ }^{8}$ whom he met in the Bank, in 1948. Let us see the perhaps most telling recollection about the personality of Herbert Enyvvári: "During his life, he always resisted the oppressive regimes' apparatus with all available means, even in peacetime after the war. During communism, he stood with two bags of potatoes in his hands during the compulsory official assemblies in the bank (!) so that he did not have to clap" (Miklauzič, 2013b: 37). Herbert Enyvvári's caricatures and illustrations were the cornerstones of the Forint's character. ${ }^{9}$ Although many people ${ }^{10}$ followed him in this position, his subtle drawings, unique graphic style, humour and exceptional attitude would have been impossible to imitate.

\footnotetext{
8 Éva Rákóczy, a descendant of the aristocratic Rákóczy family, also joined the Bank in 1945. She was first employed in the Tax Division and then in the Legal Department. One of her ancestors was János Rákóczy, "the secretary and closest confidante of Lajos Kossuth, János Damjanich's brother in arms, a fervent supporter of Sándor Petőfi, the lifelong friend to Imre Madách and Mór Jókai, the intellectual partner of Hungarian patriots, a commanding figure of the army's leaders, supporting the 1848-1849 freedom struggle with an independent cavalry troop" (Miklauzič, 2013a: 5).

${ }^{9}$ Digitized publications can be viewed in the Library of Magyar Nemzeti Bank.

${ }^{10}$ The first to take over the illustration work was András Káspári, another staff member at the central bank (occasionally in 1978-1979, then mostly between 1984 and 1990), and there was a short interim period (1982-1983) when the illustrations in the journal were mainly prepared by Dr Ferenc Kesztyüs. From the 1990s, the Forint started publishing the works (or reproductions) of professional caricaturists, mostly László Dluhopolszky (DLUHO) and Jenö Dallos.
} 


\section{Other publications}

The Referáló Lapok (Reports) series published between 1965 and 1980 (Figure 4) included summaries of articles that appeared in the general economics and financial papers of the socialist countries, covering different topics in each issue. The Tanulmányok (Studies) series had the same image in 1960 when it was launched, but it was "rebranded" around 1964 (Figure 5).

\section{Figure 4 \\ Covers of the Referáló Lapok series in 1977}
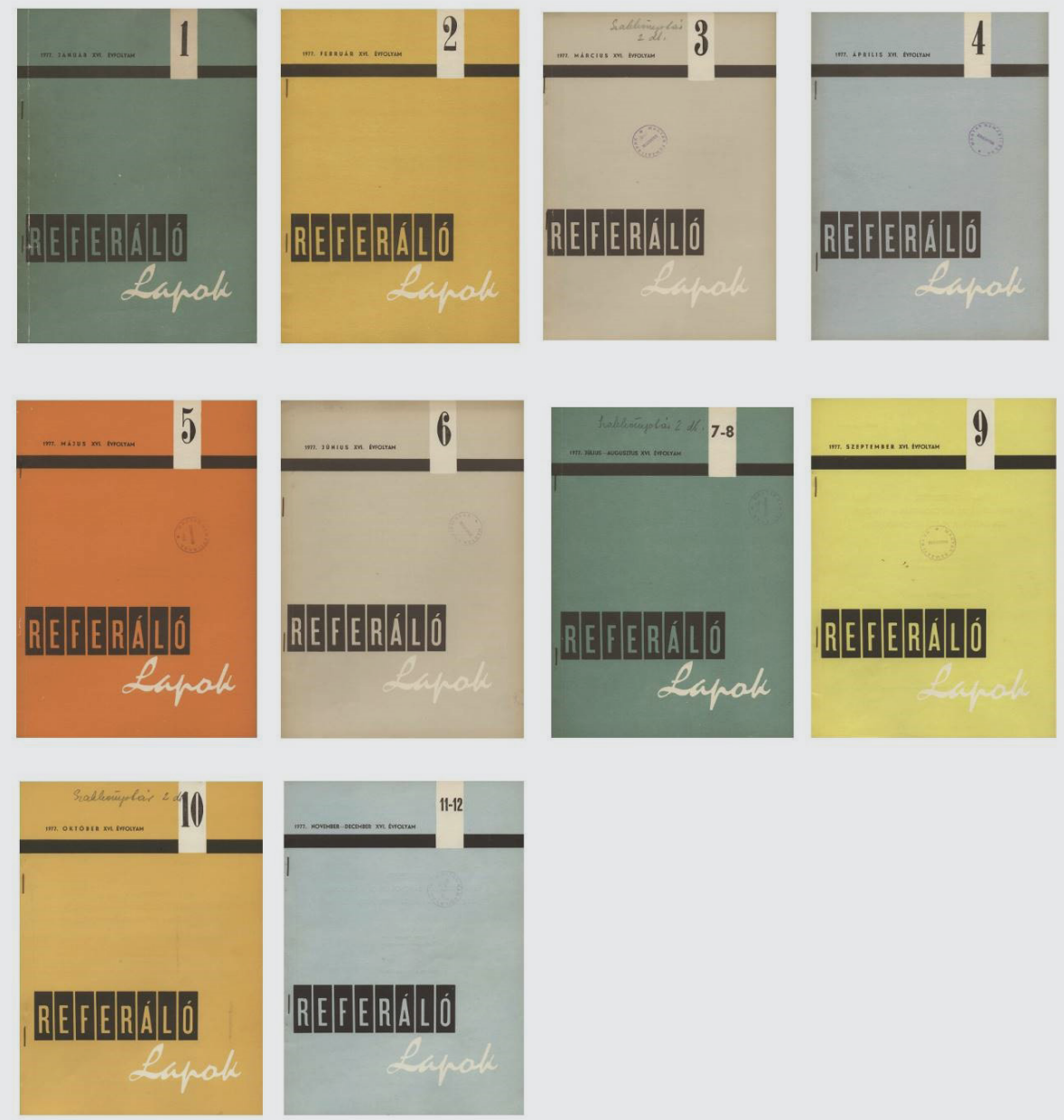


\section{Figure 5}

Final covers of the Tanulmányok series

(around 1963-1964)
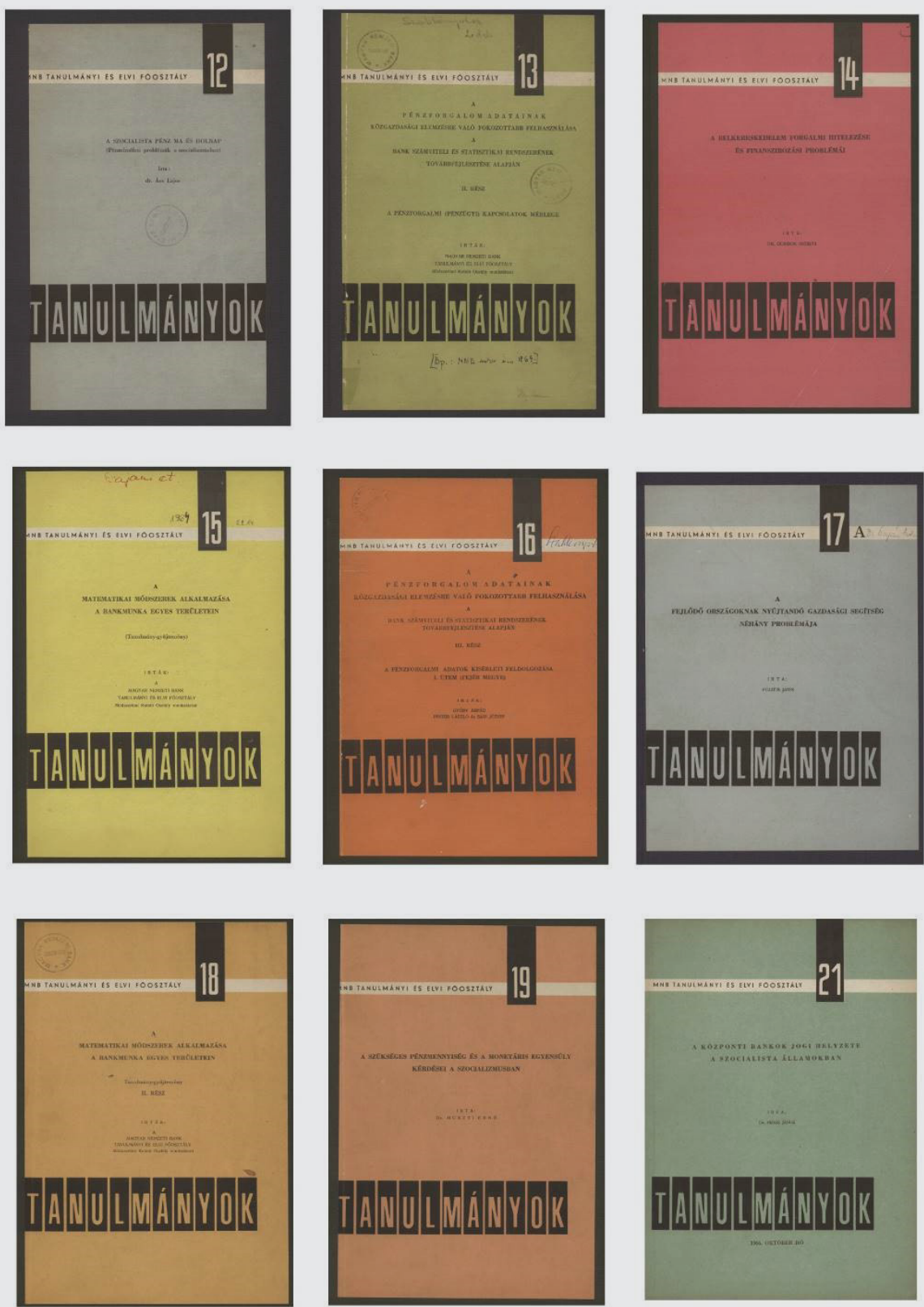
The covers in both series use different colours, but are still characterised by a recurring look at certain intervals. On account of the variety of covers and the typographical solutions, to the eyes of the modern reader these were perhaps the two series of the Bank with the most interesting content and the most uniform visual image. ${ }^{11}$

The Közgazdasági Irodalmi Szemle (Economic Literature Review) (Figure 6) was launched by the Economic Department. The series was published between September 1940 and June 1944 (Botos, 1999: 256-257), with the aim of supporting and facilitating the professional awareness of the Bank's staff through reviews of

\section{Figure 6 \\ Rebranding of the covers of the Könyvismertetések, the Folyóiratszemle and the Közgazdasági Irodalmi Szemle}
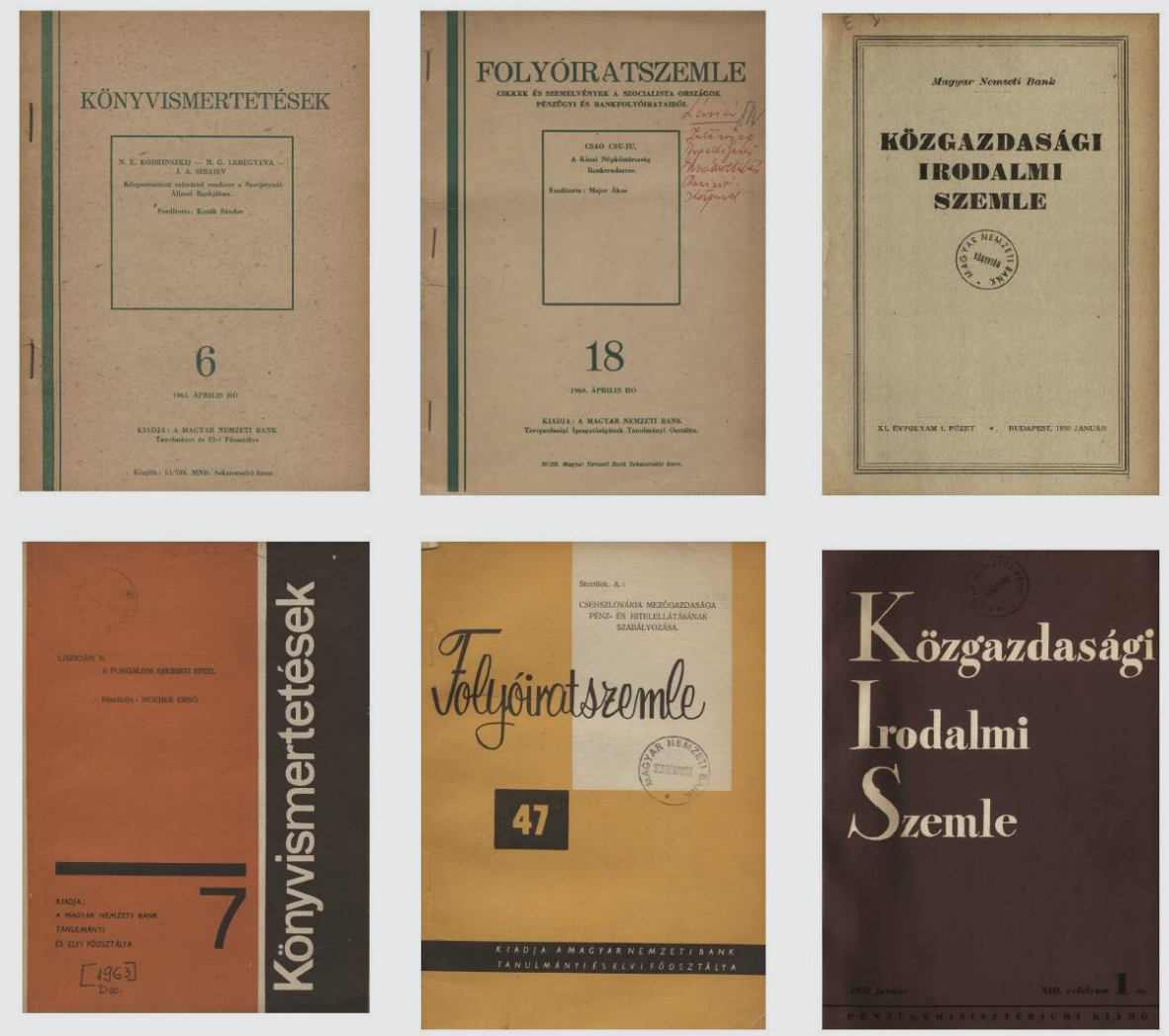

\footnotetext{
${ }^{11}$ There are remarkable similarities between the style of the covers and the character of the currently very popular handbook series of the Harvard Business Review (HBR) Press. Both use a sleek design and simple colours and typography for the covers of their publications. The "only" difference is that the HBR series also includes demonstrative illustrations.
} 
foreign literature. After processing the articles published in Hungarian journals ${ }^{12}$ with an explicit focus on banking, the reviews were divided into seven topics ${ }^{13}$ for the readers. By contrast, the Folyóiratszemle (Journal Review) (Figure 6) provided detailed information on the monetary and credit management methods of socialist countries and the theoretical articles published in official journals. As suggested by the title, the Könyvismertetések (Book Reviews) (Figure 6) sought to present books aimed at a professional audience.

The Közgazdasági Föosztály Közleményei (Publications of the Economics Department) series (Figure 7) was published between July 1969 and August 1989, with various longer professional and scientific studies, treatises and summaries by the Bank's staff. It was very close, or, we could say, a forerunner in style to the

\section{Figure 7 \\ Covers of the Közgazdasági Föosztály Közleményei in 1969 (Issue 1) and in 1983 (Issue 107)}

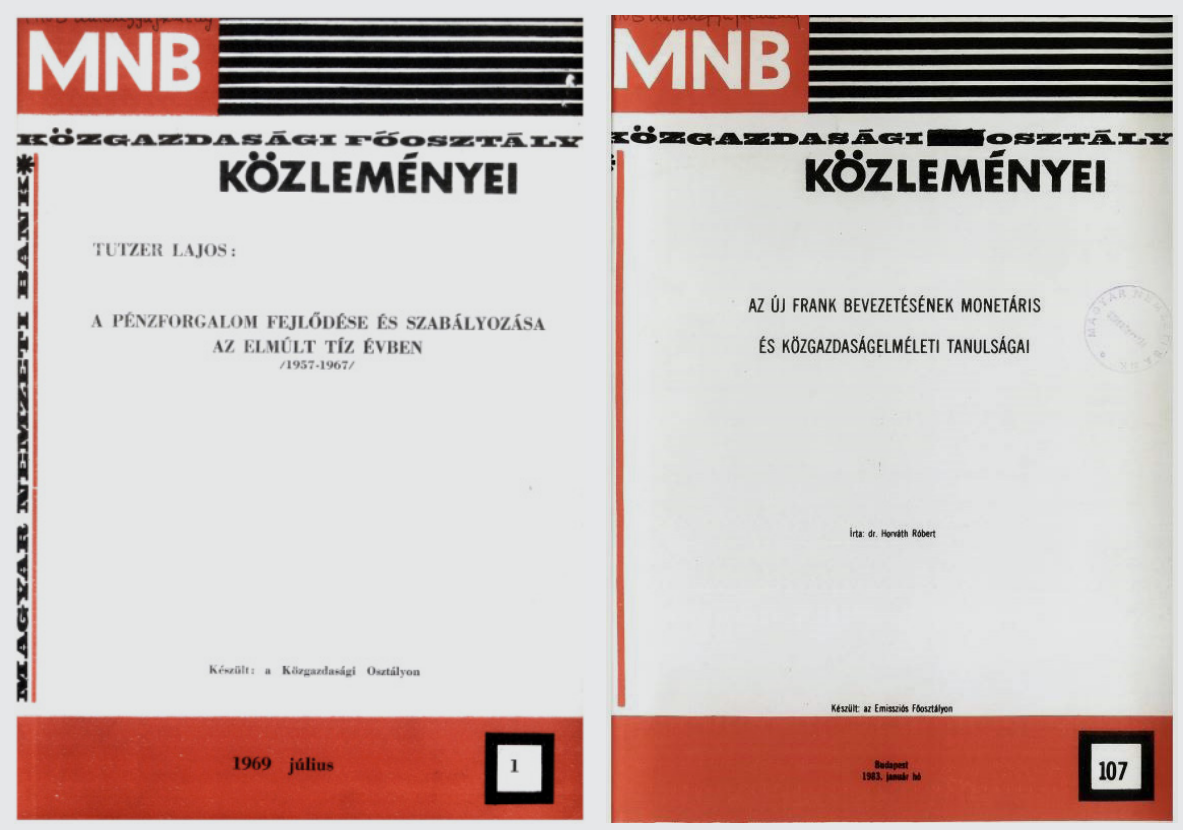

Note: The reason why Issue 107 from 1983 is shown here is that from then on, later issues were available only in black and white in the digital archive of the Magyar Nemzeti Bank (Nainuwa). However, except for the colours, everything appeared as in the previous issues. Nevertheless, in order to illustrate the visual continuity, the last colour-cover issue available in the archive is included here.

\footnotetext{
12 In the Bankszemle (Bank Review), the Gazdaság (Economy), the Közgazdasági Szemle (Economic Review), the Külkereskedelem (Foreign Trade), the Pénzügyi Szemle (Financial Review) and the Társadalmi Szemle (Social Review).

${ }^{13}$ The issues of general finance, income regulation, budget, lending, payments, FX management, foreign trade and investment finance.
} 
MNB Füzetek launched at the turn of 1995 and 1996, ${ }^{14}$ the idea of which originated from György Szapáry, ${ }^{15}$ and to the MNB Occasional Papers launched in the autumn of $2005 .{ }^{16}$ During the 30 years of this series, a total of 117 issues appeared, the special feature of which was not the cover of the series, which was unusually unique and incongruous with the world of banking, just like its typography, but the fact that it was able to appear with the same look and structure all throughout its existence.

We must also mention another publication, the series published by the Education Department, ${ }^{17}$ established in 1952 (Figure 8). The department was tasked with the uniform supervision of the internal and partly external professional trainings of the Bank at that time (Botos - Botos, 2004: 138). The publications for mostly internal circulation, produced in various print runs, providing comprehensive and concise professional advice and task descriptions to the staff in a topic or position, were probably published because of this from 1953. The publications were published by Pénzügyi Kiadó, and the covers were using soft colours (grey, white, dark brown).

\section{Summary}

Nowadays, the importance of the visual image and especially visual communication is undeniable. The method, channel, structure and "external look" of communication are critical, despite seeming insignificant and non-essential, and they should form an integral part of professional and scientific life. This is because by nature, visual images and visual communication raise awareness and guide us, which may facilitate the processing of the content geared towards professionals. In a world where the available information multiplies day by day, it is much harder, but not impossible, to stand out from the "crowd" of professional communication. Well-structured organisations, journals and series with a uniform visual image can communicate continuity, stability and reliability towards the outside world. Over the longer term, accessing, structuring and categorising the visual image of an organisation's professional materials paves the way for using the visual foundations as a platform in order to make the organisation's content geared towards professionals stand out even more from the crowd, thereby drawing attention to the organisation.

\footnotetext{
${ }^{14}$ The MNB Füzetek was first published only in Hungarian, and then - in line with similar international publications - only in English, and, accordingly, it was renamed MNB Working Papers and is still published today.

${ }^{15}$ Deputy Governor of the Magyar Nemzeti Bank between 1993 and 1999, and 2001 and 2007, and currently chief advisor to the Governor of the Magyar Nemzeti Bank.

${ }^{16}$ The MNB Occasional Papers combined the MNB Háttértanulmányok (MNB Background Studies) series and the MNB Múhelytanulmányok (MNB Workshop Studies) series published before the autumn of 2005 and is still published by the Magyar Nemzeti Bank.

${ }^{17}$ The Education Department, which was in charge of the publication, was created in November 1952. It sought to provide assistance in the professional training of the colleagues in the national network of regional offices, county branches and branch offices established between 1950 and 1956 . The department operated for three years and was then merged into the HR Department in 1955.
} 
Presentation of the Hungarian Publications of the Magyar Nemzeti Bank...

\section{Figure 8}

Covers of the publications by the Education Department of the Magyar Nemzeti Bank in 1953
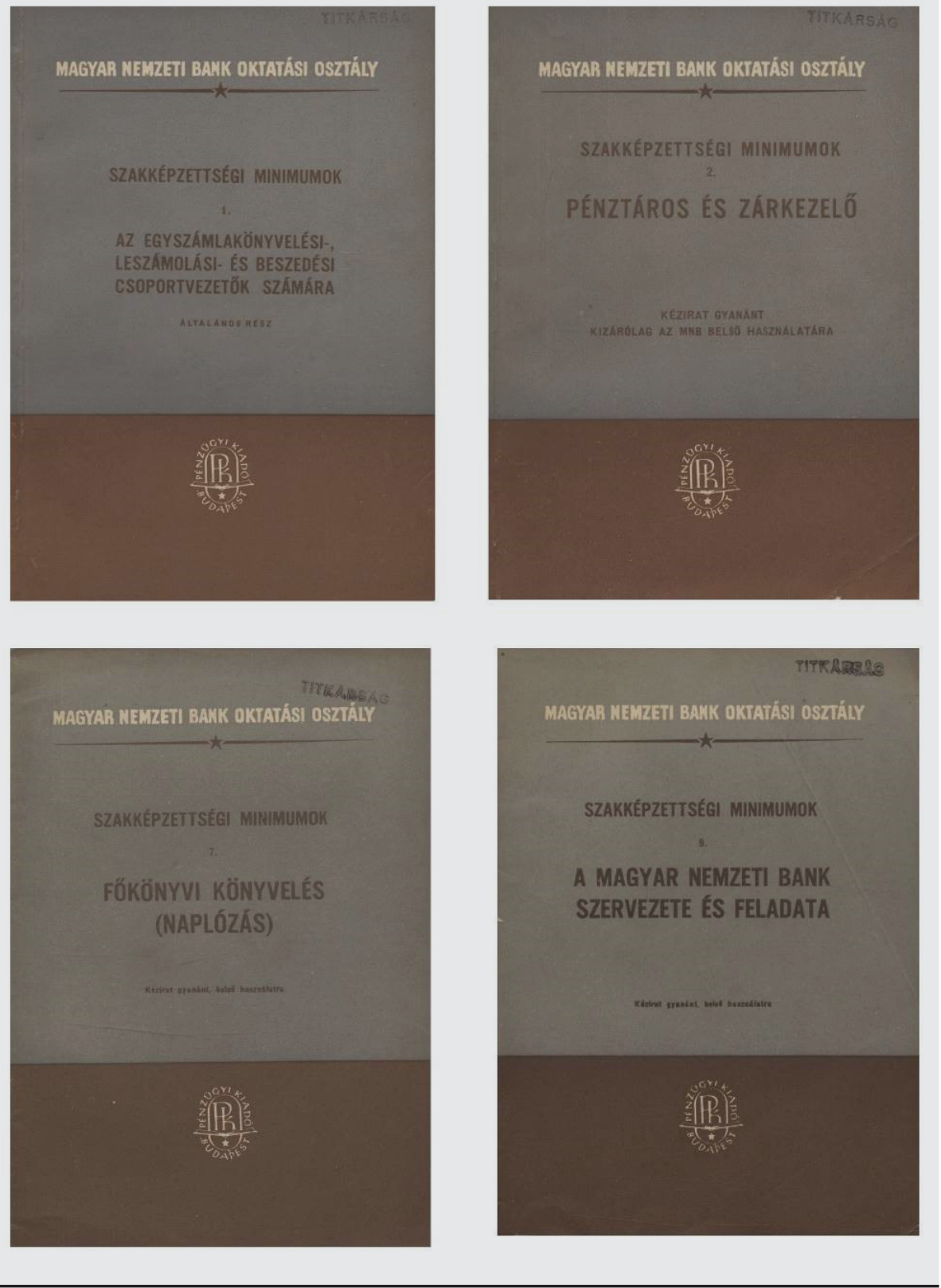
I believe that the present description may be of interest not only because of its special nature, but also because it may point out aspects for the future that can help the further development of the Bank's and its publications' external and internal communication.

\section{References}

Botos, J. (1999): A Magyar Nemzeti Bank története II. kötet - Az önálló jegybank 1924 -1948 (History of the Magyar Nemzeti Bank, Volume II - The Independent Central Bank 1924-1948). PressCon Kiadó Kft, p. 399.

Botos, J. - Botos, K. (2004): A Magyar Nemzeti Bank története III. kötet - A jegybank útja rendszerváltozástól rendszerváltozásig 1948-1989 (History of the Magyar Nemzeti Bank, Volume III - The Central Bank from One Political Transition Until the Next 1948-1989). Tarsoly Kiadó, Budapest, p. 753.

Miklauzič, I. (2013a): A nemesi Rákóczy-család. Történelmi életutak (The Aristocratic Rákóczy Family. The Lives of Historical Figures) Mécses Sorozat, Székely Ház Közhasznú Alapítvány, p. 137.

Miklauzič, I. (2013b): A Mikó - Nyiredy - Arlow család. Prémszövők, méneskariak és a rendithetetlenek kopjafája (The Mikó-Nyiredi-Arlows. Fur Weavers, Cavalry Officers and the Wooden Memorial Columns of the Dauntless). Mécses Sorozat, Székely Ház Közhasznú Alapítvány, p. 196. 